\title{
Modification of Yellow River Sediment Based Stabilized Earth Bricks
}

DOI: $10.15255 /$ KUI.2016.023

KUI-42/2016

Professional paper

Received June 24, 2016

Accepted October 20, 2016

\author{
J.-X. Liu, ${ }^{a^{*}}$ R. Hai, and L. Zhang ${ }^{\text {b }}$ \\ a College of Architecture Engineering, Zhongyuan University of Technology, \\ Zhengzhou 450 007, P.R. China \\ ${ }^{b}$ Department of Materials Engineering, Tianjin Chengjian University, \\ Tianjin 300 384, P.R. China
}

\begin{abstract}
\| Abstract
This paper presents an experimental study on the microstructure and performance of stabilized earth bricks prepared from the Yellow River sediment. The sediment is modified by inorganic cementitious material, polymer bonding agent, and jute fibre. The results show that the sediment is preliminarily consolidated when the mixture ratio of activated sediment/cementitious binder/sand is 65/25/10. Compressive strength and softening coefficient of stabilized earth bricks is further improved by polymer bonding agent and jute fibre. SEM images and EDS spectral analysis indicate that there is indeed synergy among inorganic hydration products, polymer network and jute fibre to strengthen the sediment.
\end{abstract}

$\|$ Keywords

Yellow River sediment, stabilized earth bricks, strengthening network, synergy

\section{Introduction}

Minerals of the Yellow River sediment are mainly composed of silica, feldspar, calcite and clay, and can be used for preparation of new building materials, functional materials, ceramic and glass products. ${ }^{1-4}$ However, most of these products are prepared by the sintering process, which not only has high production cost, but also produces large secondary pollution. Therefore, some improvement should be made in order to realize the utilization of sediment with low energy consumption.

Soil modification experience can be taken as a reference to promote the utilization of the Yellow River sediment for environment-friendly building materials. S. Burroughs ${ }^{5}$ analysed 104 soil types that were compacted and stabilized with lime or cement among a total of 219 mixtures, and concluded that a soil could be suitable for stabilization while its compressive strength exceeded $2 \mathrm{MPa}$. D. Ciancio et al. ${ }^{6}$ adopted lime to stabilize clay. Samples tested in ambient conditions presented a compressive strength peak for a value of porosity/lime $(\mathrm{n} / \mathrm{l})$ ratio corresponding to lime content between $3 \%$ and $4 \%$. M. Emiroğlu et al. ${ }^{7}$ concluded that the optimum mixing ratios for raw materials (clay and sand) were between 0.43 and 0.66 by weight according to compressive strength and plasticity. Alfred et al. ${ }^{8}$ adopted different proportions of vegetable fibre to improve the compressive strength and weather resistance of raw soil materials. V. Sharma et al. ${ }^{9}$ indicated that the UCS value of low compressive clay had significantly increased

${ }^{*}$ Corresponding author: Junxia Liu, Ph.D

e-mail: liujunixia80600@163.com with the addition of natural fibres. The increase in strength was $73-137 \%$ for fibres of Pinus roxburghii and 94-200\% for fibres of Grewia optivia.

In this work, the possibility of preparing stabilized earth bricks from Yellow River sediment has been explored. It should be noted that the sediment scoured by the Yellow River has a very low content of clay particles and poor reactivity, which cannot meet the requirements of raw soil materials. In view of this, the sediment was activated by sodium bisulphate in order to improve its reactive activity and stabilizability. The stabilized earth bricks were then prepared from the activated sediment by modification with inorganic cementitious material, polymer bonding agent, and jute fibre. Further, the synergy and consolidation mechanism of three stabilized measures are systematically studied.

\section{Experimental}

\subsection{Materials}

The Yellow River sediment comes from Huayuankou at the lower reaches of the Yellow River. Its moisture content is between $41-47 \%$. XRD patterns of the nature and activated sediment are shown in Fig. 1. The chemical composition of the Yellow River sediment, Ordinary Portland Cement (OPC) type CEM I $42.5 \mathrm{~N}$ and fly ash, which is determined by complete chemical analysis, is given in Table 1 . The mechanical properties of Portland cement mortars of CEM I $42.5 \mathrm{~N}$ are listed in Table 2. The mass fraction of siliceous lime's calcium oxide and magnesium oxide is $82 \%$. Fly ash 
is from Kaifeng coal-fired power plant, pozzolanic activity index is 0.97 according to Chinese national standards of fly ash (GB/T 1596-2005) used for cement and concrete. The length, aspect ratio, and density of jute fibre are $8.0 \mathrm{~mm}$, 70 and $1.2 \mathrm{~g} \mathrm{~cm}^{-3}$, respectively. The morphology and SEM image of jute fibre are shown in Fig. 2. Polymer bonding agent is boric acid modified polyvinyl alcohol solution with solid mass fraction $10 \%$, and self-made in the laboratory. The polymerization degree of polyvinyl alcohol is 1799, boric acid is analytical reagent.

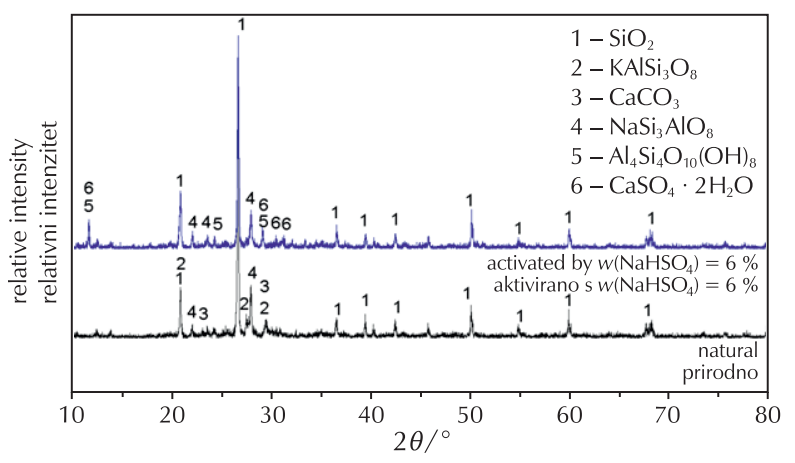

Fig. 1 - XRD patterns of the nature and activated sediment Slika 1 - Rendgenogram prirodnog i aktiviranog sedimenta

Table 1 - Chemical composition of the Yellow River sediment, CEM I 42.5N cement and fly ash

Tablica 1 - Kemijski sastav sedimenta rijeke Huang He, cementa CEM I $42.5 \mathrm{~N}$ i lebdećeg pepela

\begin{tabular}{l|c|c|c}
\hline $\begin{array}{c}\text { Component } \\
\text { Sastojak }\end{array}$ & $\begin{array}{c}\text { Yellow River sediment } \\
\text { Sediment rijeke } \\
\text { Huang He }\end{array}$ & CEM I 42.5N & $\begin{array}{c}\text { Fly ash } \\
\text { Lebdeći } \\
\text { pepeo }\end{array}$ \\
\hline$w\left(\mathrm{SiO}_{2}\right) / \%$ & 70.9 & 17.8 & 58.2 \\
$w\left(\mathrm{Al}_{2} \mathrm{O}_{3}\right) / \%$ & 9.1 & 5.7 & 27.5 \\
$w(\mathrm{CaO}) / \%$ & 6.1 & 59.7 & 4.2 \\
$w\left(\mathrm{Fe}_{2} \mathrm{O}_{3}\right) / \%$ & 3.0 & 3.2 & 4.8 \\
$w\left(\mathrm{~K}_{2} \mathrm{O}\right) / \%$ & 2.1 & 1.0 & - \\
$w\left(\mathrm{Na}_{2} \mathrm{O}\right) / \%$ & 2.1 & 0.2 & - \\
$w(\mathrm{MgO}) / \%$ & 1.3 & 3.1 & 1.4 \\
$w($ others $) / \%$ & 5.4 & 9.3 & 3.9 \\
\hline
\end{tabular}
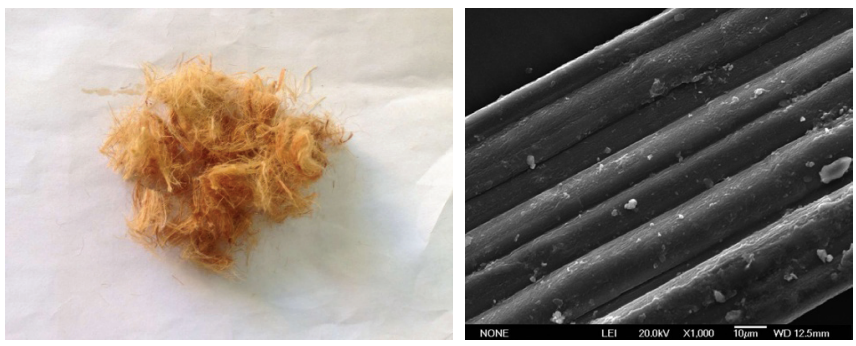

Fig. 2 - Macromorphology and SEM image of jute fibre Slika 2 - Makromorfologija i SEM vlakana jute
Table 2 - Mechanical properties of Portland cement mortars Tablica 2 - Mehanička svojstva morta portland-cementa

\begin{tabular}{c|c|c}
\hline $\begin{array}{c}\text { Time/days } \\
\text { Vrijeme/dani }\end{array}$ & $\begin{array}{c}\text { Compressive } \\
\text { strength/MPa } \\
\text { Tlačna čvrstoća/MPa }\end{array}$ & $\begin{array}{c}\text { Flexural strength/MPa } \\
\text { Savojna čvrstoća/MPa }\end{array}$ \\
\hline 3 & 29.0 & 5.9 \\
28 & 53.4 & 8.8 \\
\hline
\end{tabular}

\subsection{Specimens}

Activated sediment is taken as the main raw material to prepare stabilized earth bricks through modification by cementitious material (mass ratio of cement, lime, and fly ash $=1: 1: 1.2$, polymer bonding agent, and jute fibre (Table 3 ). The bricks are prepared by stirring and vibro-moulding process, and the specimen size is $240 \mathrm{~mm} \times 115 \mathrm{~mm} \times 53 \mathrm{~mm}$. Afterwards, the specimens are cured at $15-25{ }^{\circ} \mathrm{C}$ and relative humidity about $80 \%$. The images of activated sediment, fresh mixture of stabilized earth bricks and final product are shown in Fig. 3.
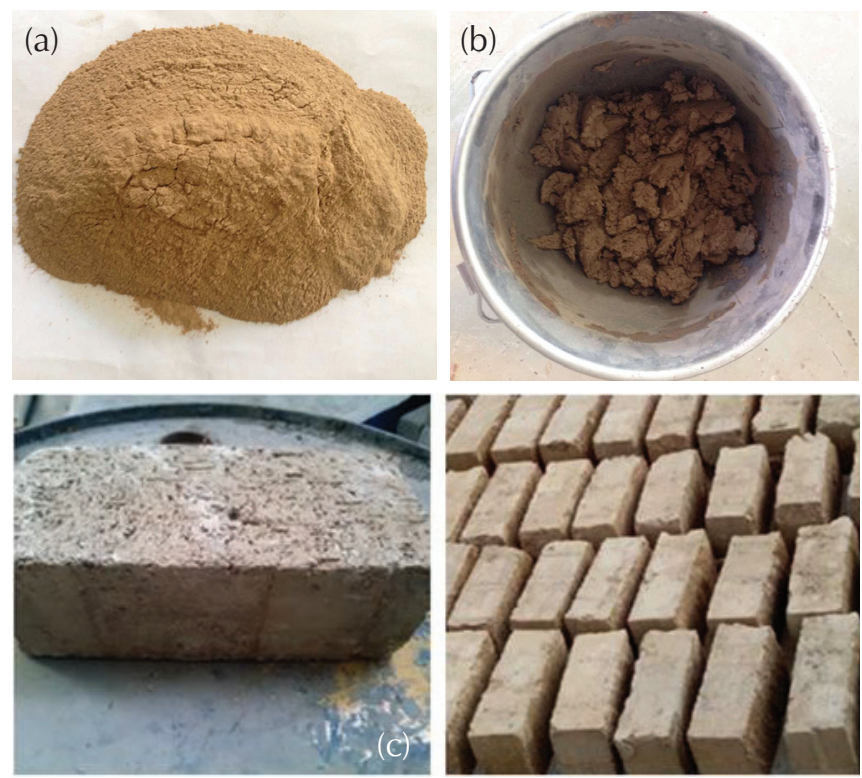

Fig. 3 - Activated sediment (a), fresh mixture of stabilized earth bricks (b), and final products (c)

Slika 3 - Aktivirani sediment (a), svježa smjesa za stabilizirane zamljane opeke (b), konačni proizvod (c)

The softening coefficient is an important index to measure water resistance of raw soil materials. According to the relevant methods of raw soil materials, ${ }^{10}$ it can be viewed as the compressive strength ratio of specimens that are cured for 28 days and those cured for 27 days, then immersed in water for $24 \mathrm{~h}$ at about $20^{\circ} \mathrm{C}$. 
Table 3 - Mixing proportions of stabilized earth bricks

Tablica 3 - Sastav smjese za stabilizirane zemljane opeke

\begin{tabular}{|c|c|c|c|c|c|}
\hline \multirow{2}{*}{$\begin{array}{c}\text { Code } \\
\text { Br. }\end{array}$} & \multicolumn{4}{|c|}{$w / \%$} & \multirow{2}{*}{$\begin{array}{c}\varphi / \% \\
\text { jute fibre* } \\
\text { jutena vlakna* }\end{array}$} \\
\hline & $\begin{array}{l}\text { activated sediment } \\
\text { aktivirani sediment }\end{array}$ & $\begin{array}{l}\text { inorganic cement } \\
\text { anorganski cement }\end{array}$ & $\begin{array}{l}\text { sand } \\
\text { pijesak }\end{array}$ & $\begin{array}{l}\text { polymer binder* } \\
\text { polimerno vezivo* }\end{array}$ & \\
\hline 1 & 80 & 16 & 4 & - & - \\
\hline 2 & 75 & 19 & 6 & - & - \\
\hline 3 & 70 & 22 & 8 & - & - \\
\hline 4 & 65 & 25 & 10 & - & - \\
\hline 5 & 62 & 28 & 10 & - & - \\
\hline $6-11$ & 65 & 25 & 10 & $0.9-2.4$ & - \\
\hline $12-19$ & 65 & 25 & 10 & - & $0.2-1.6$ \\
\hline 20 & 65 & 25 & 10 & 1.8 & 1.0 \\
\hline
\end{tabular}

* Polymer bonding agent and jute fibres were mixed by external addition

Polimerno vezivo i juta dodani su naknadno

\subsection{Microscopic analysis}

The hydration of earth specimens is terminated with alcohol at 28 days. After drying at $60{ }^{\circ} \mathrm{C}$ to constant weight, the sections of the specimens are sprayed with gold. The developed microstructure was investigated by Field Emission Scanning Electron Microscopes model JSM-6700F, equipped with Energy-Dispersive X-ray Spectroscopy. The mineral composition of the Yellow River sediment was examined by $X$ ray diffraction model LabX XRD6000 .

\section{Results and discussion}

\subsection{Factors affecting the performance of stabilized earth bricks}

\subsubsection{Influence of inorganic cementitious materials}

As expected, the compressive strength and softening coefficient of the specimens both increase with the increase in inorganic cementitious materials. Compressive strength increases from 4.3 MPa to7.1 $\mathrm{MPa}$ when inorganic cementitious materials increases from $16 \%$ to $25 \%$ (Fig. 4). After that, the increasing speed of compressive strength obviously declines. In addition, the water resistance increases with the increase in inorganic cementitious materials, indicating that the inorganic cementing network can provide preliminary solidification for the sediment. In order to balance between the maximum use of the Yellow River sediment and the basic requirements of the product properties, the appropriate content of inorganic cementitious materials is determined as $25 \%$ (specimen 4).

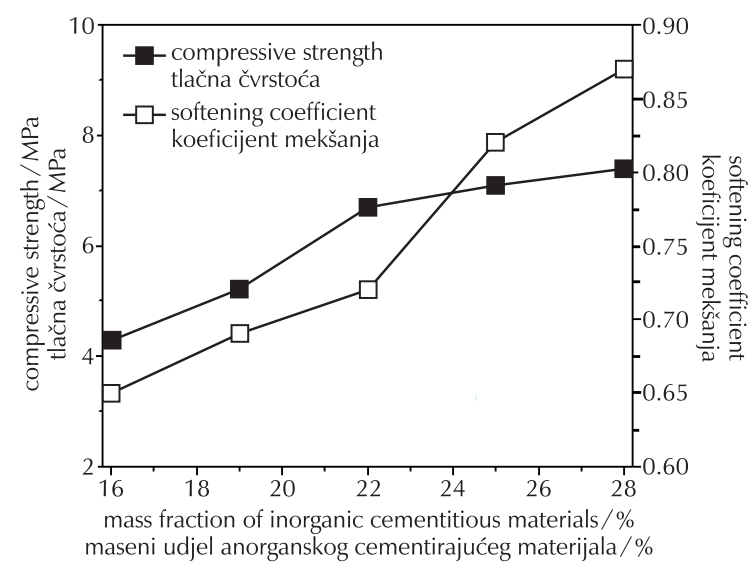

Fig. 4 - Dependency of the mechanical performance of stabilized earth bricks at 28 days on mass fraction of inorganic cementitious materials

Slika 4 - Ovisnost mehaničkih svojstava stabilizirane zemljane opeke nakon 28 dana o udjelu cementnog materijala

\subsubsection{Influence of polymer bonding agent}

Compressive strength at 28 days significantly increases with the incorporation of polymer bonding agent, as may be seen from Fig. 5, and reaches 12.6 MPa when the dosage of polymer bonding agent is $1.8 \%$, which is 1.7 times that of specimen 4. It is noticed that physical and chemical actions between the polymer and the sediment particles, including hydrogen bonding, flocculation and adsorption, can form a spatial polymer system along with the hydration process of inorganic cementitious material, which consolidates stabilized earth bricks. The networks twist together with each other, and thus improve the strength and resistance of stabilized earth bricks. 


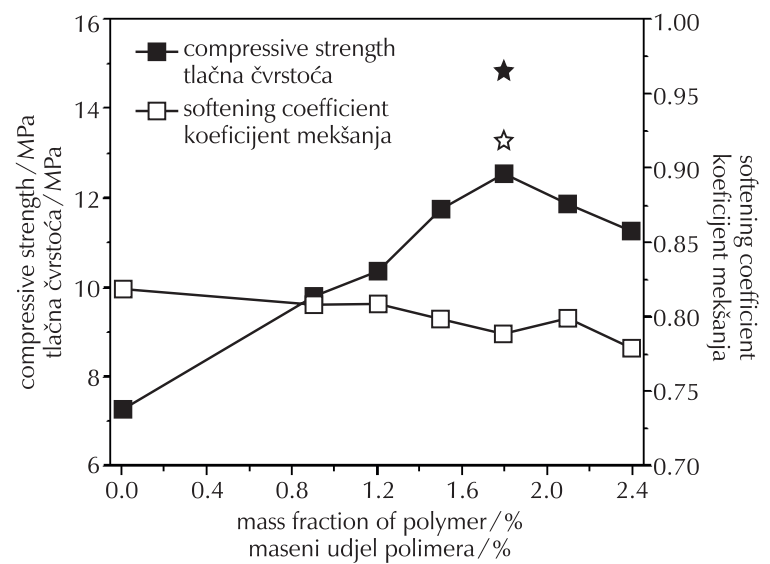

Fig. 5 - Dependency of the mechanical performance of stabilized earth bricks at 28 days on polymer mass fraction

Slika 5 - Ovisnost mehaničkih svojstava stabilizirane zemljane opeke nakon 28 dana o udjelu polimera

\subsubsection{Influence of jute fibre}

The compressive strength of the stabilized earth bricks reaches 9.4 $\mathrm{MPa}$, when jute fibre volume fraction is $1.2 \%$ (Fig. 6), which is $32 \%$ higher than that of specimen 4 . Meanwhile, although the softening coefficient presents a slight fluctuation, it still maintains above 0.9. Jute fibre can form a staggered three-dimensional structure in the specimens, thus producing crack branches. The take-down cracks can absorb parts of the damaging energy and slow down the speed of crack extension when deformation occurs.

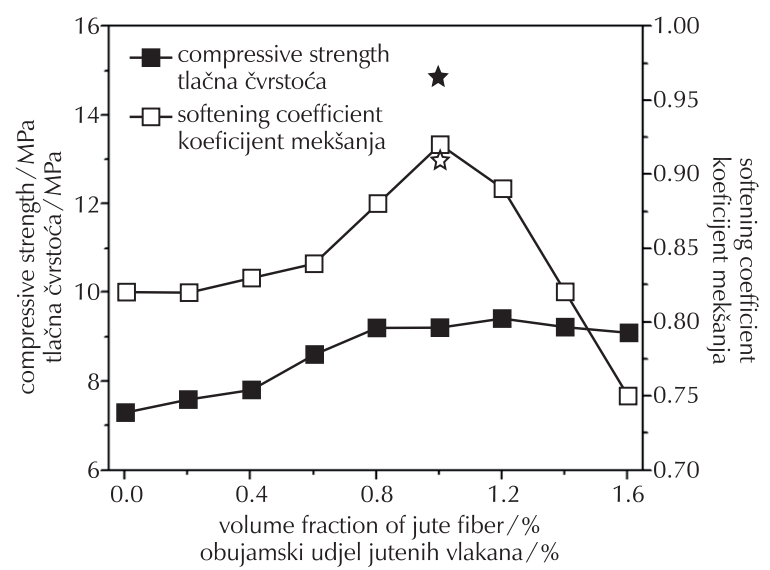

Fig. 6 - Dependency of the mechanical performance of stabilized earth bricks at 28 days on mass fraction of inorganic cementitious materials

Slika 6 - Ovisnost mehaničkih svojstava stabilizirane zamljane opeke nakon 28 dana o udjelu vlakana jute

\subsection{Performance and microstructure of stabilized earth bricks}

\subsubsection{Performance of stabilized earth bricks}

According to the above experimental results, the optimal dosages of polymer bonding agent and jute fibre are mass fraction $1.8 \%$ and volume fraction $1.0 \%$, respectively. Specimen 20 is prepared with the optimal dosages. $\star$ in Figs. 5 and 6 represents the compressive strength of specimen 20, and represents the softening coefficient. The compressive strength and softening coefficient of specimen 20 are $15.1 \mathrm{MPa}$ and 0.91 respectively, which indicates that jute fibre can make up for the negative effects of polymer bonding agent on softening coefficient. Moreover, the Yellow River sediment can be primarily stabilized by inorganic cementitious material. Meanwhile, the addition of the crack resistant fibre combined with organic polymer dispersion can consolidate and strengthen the matrix. Therefore, the three sets of systems have positive synergistic effects.

\subsubsection{Microstructure of stabilized earth bricks}
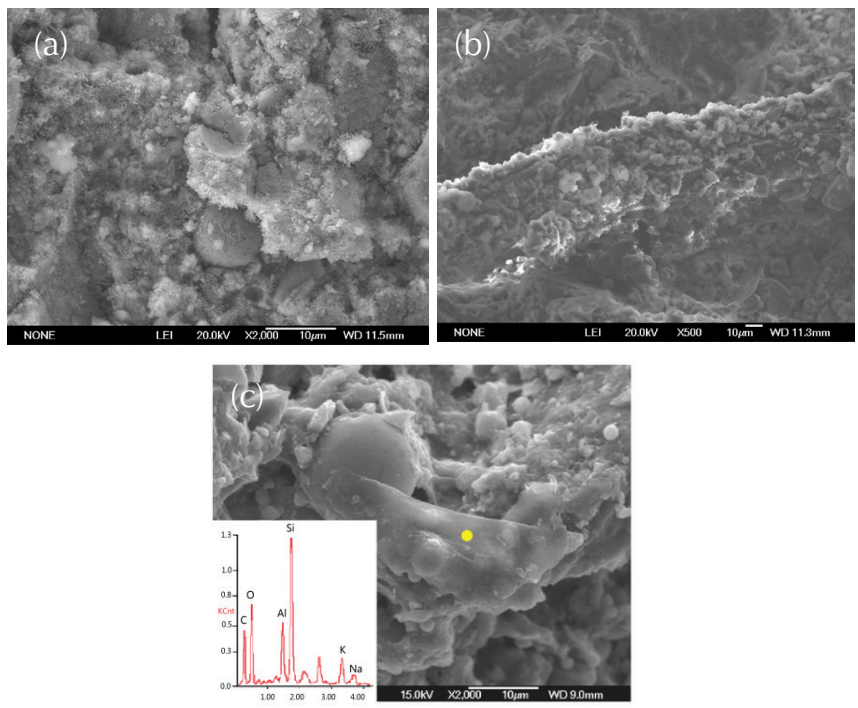

Fig. 7 -SEM image (a), pulled-out fibre surface morphology (b), and EDS spectrum (c) of stabilized earth bricks at 28 days

Slika 7 -SEM-mikrografije stabilizirane zemljane opeke nankon 28 dana (a), morfologija površine vlakna (b) i EDS-spektar (c)

The SEM images of specimen 20 shows that coarse sand and fragmented particles are submerged in the flocculent hydration products (Fig. 7a), demonstrating that the Yellow River sediment is effectively consolidated and strengthened by the inorganic cementitious materials. The consolidation and strengthening ensure a considerable mechanical properties and water resistance of the stabilized earth bricks. As Fig. 7b shows, the surface of the pulled-out fibre is rough and uneven, and it is wrapped with a large amount of hydration products. This indicates that good bonding is formed between jute fibre and the matrix. Under external force, the mechanical energy is consumed by the hydration products separated from the matrix in the process of pulling out of the jute fibre, thereby increasing the mechanical properties of the stabilized earth bricks.

Fig. 7c represents the SEM image and EDS spectrum of the section microstructure corroded by dilute $\mathrm{HCl}$. The EDS analysis (Table 4) shows that the element composition of carbon is $56.55 \%$ in the scanning area, which infers that material composition of the region is polymer binder. 
Combined with EDS, the SEM image in Fig. 7c shows that polymer wraps around the coarse sand and sediment particles, and forms a semi-continuous network in the local area. This improves the mechanical properties of the Yellow River sediment by physical bonding.

Table 4 - EDS analysis of the round point in Fig. 7C Tablica 4 - EDS-analiza točke na slici 7c

\begin{tabular}{c|c|c|}
\hline Element & $\begin{array}{c}\text { Mass fraction } / \% \\
\text { Maseni udjel } / \%\end{array}$ & $\begin{array}{c}\text { Amount fraction } / \% \\
\text { Množinski udjel } \%\end{array}$ \\
\hline $\mathrm{C}$ & 43.30 & 56.55 \\
$\mathrm{O}$ & 30.07 & 29.48 \\
$\mathrm{Al}$ & 5.38 & 3.13 \\
$\mathrm{Si}$ & 14.88 & 3.31 \\
$\mathrm{~K}$ & 4.67 & 1.87 \\
$\mathrm{Ca}$ & 1.71 & 0.67 \\
\hline
\end{tabular}

According to the above analysis, inorganic cementitious material can be considered as the basic network to consolidate the Yellow River sediment, while jute fibre and polymer is the assisted modifier to improve the strength and water resistance of stabilized earth bricks. These three sets of network can form continuous, semi-continuous, and overlapping systems, and thus strengthen and consolidate the Yellow River sediment.

To sum up, stabilized earth bricks can be prepared with $65 \%$ sediment (the Yellow River sediment) and only about $8 \%$ cement through traditional process (vibratory compaction and standard curing), and mechanical performance of the prepared bricks can meet the demand of MU10 according to the Chinese GB/T5101-2003. The stabilized earth bricks are capable of eliminating a large amount of the Yellow River channel sediment at the cost of the lowest energy consumption. Meanwhile, these bricks can be considered a new environment-friendly building material for the Lower Yellow River residents in the new rural construction area.

\section{Conclusion}

In summary, the stabilized earth bricks are successfully prepared from the Yellow River sediment modified by polymer bonding agent and jute fibre, and some conclusions can be drawn from the experimental study on compressive strength, softening coefficient and microstructure of the prepared bricks, as follows:

1. It is advisable for stabilized earth bricks to maintain the inorganic cementitious materials at no less than $25 \%$ to achieve considerable compressive strength and softening coefficient;

2. Inorganic cementitious material, polymer bonding agent, and jute fibre can improve the compressive strength and softening coefficient, and these three sets of strengthening measures have positive synergistic effects; adopting their optimal dosages, the compressive strength and softening coefficient of stabilized earth bricks are $15.1 \mathrm{MPa}$ and 0.91 respectively;

3. SEM and EDS results show that synergy among inorganic hydration products, polymer system, and jute fibre can form three sets of network, which improves physical and mechanical properties of the stabilized earth bricks.

\section{ACKNOWLEDGEMENTS}

The authors gratefully acknowledge the support from the National Key Technology R\&D Program in the $12^{\text {th }}$ Five Year Plan of China (Grant No.2014BAL03B03).

\section{List of abbreviations and symbols Popis kratica i simbola}

$$
\begin{array}{ll}
w & - \text { mass fraction, } \% \\
& - \text { maseni udjel, } \% \\
\theta & - \text { Bragg angle, }{ }^{\circ} \\
& - \text { Braggov kut, }{ }^{\circ} \\
\varphi & \text { - volume fraction, } \% \\
& \text { - obujamski udjel, } \%
\end{array}
$$

\section{References \\ Literatura}

1. P. Wang, G. G. Zheng, J. Shao, H. T. Song, Y. B. Leng, Study on the Reserved Blocks Made with Sediment in the Yellow River Via Roller Compacted Technique, Yellow River 34 (5) (2012) 12-12+31.

2. K. B. Hu, Study on Physicochemical characteristics and Phosphate adsorption behaviors of sediments from the Yellow River, MSD theses, Peking, 2011, Beijing Forestry University.

3. X. Q. Ran, Z. Z. Jing, X. H. Pan, L. Lu, H. Maeda, H. Ishida, Analysis of properties of the Yellow River silt and primary investigation on hydrothermally solidifying silt, Mater. Rev. China 24 (2010) 442-446.

4. J. X. Liu, L. Zhang, J. J. Yang, Y. L. Xiao, Activation Effect and Mechanism of Phosphoric Acid on the Yellow River Silt Limes Soil, J. Build. Mater. 16 (2013) 898-902.

5. S. Burroughs, Soil Property Criteria for Rammed Earth Stabilization, J. Mater. Civ. Eng. 20 (2007) 264-273, doi: http:// dx.doi.org/10.1061/(ASCE)0899-1561(2008)20:3(264).

6. D. Ciancio, C. T. S. Beckett, J. A. H. Carraro, Optimum lime content identification for lime-stabilised rammed earth, Constr. Build. Mater. 53 (2014) 59-65, doi: http://dx.doi. org/10.1016/j.conbuildmat.2013.11.077.

7. M. Emiroğlu, A. Yalama, Y. Erdoğdu, Performance of readymixed clay plasters produced with different clay/sand ratios, Appl. Clay Sci. 115 (2015) 221-229, doi: http://dx.doi. org/10.1016/j.clay.2015.08.005.

8. S. M. Hejazi, M. Sheikhzadeh, S. M. Abtahi, A. Zadhoush, A simple review of soil reinforcement by using natural and synthetic fibers, Constr. Build. Mater. 30 (2012) 100-116, doi: http://dx.doi.org/10.1016/j.conbuildmat.2011.11.045. 
9. V. Sharma, H. K. Vinayak, B. M. Marwaha, Enhancing compressive strength of soil using natural fibers, Constr. Build. Mater. 93 (2015) 943-949, doi: http://dx.doi.org/10.1016/j. conbuildmat.2015.05.065.
10. A. Guettala, A. Abibsi, H. Houari, Durability study of stabilized earth concrete under both laboratory and climatic conditions exposure, Constr. Build. Mater. 20 (2006) 119-127, doi: http://dx.doi.org/10.1016/j.conbuildmat.2005.02.001.

\section{SAŽETAK}

\section{Stabilizirane zemljane opeke načinjene od sedimenta rijeke Huang $\mathrm{He}$

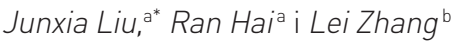

Eksperimentalno su proučena mikrostruktura i svojstva stabilizirane zemljane opeke načinjene od sedimenta rijeke Huang He (Žuta rijeka). Sedimentu su pridodani anorganski cement, polimerno vezivo i jutena vlakna. Prema rezultatima sediment je prethodno konsolidiran kada je u smjesi maseni omjer aktiviranog sedimenta, cementa i pijeska $65: 25$ : 10. Tlačna čvrstoća i koeficijent omekšivanja stabilizirane zemljane opeke dodatno su poboljšani polimernim vezivom i jutenim vlaknima. Snimke SEM-om i analiza EDS-om pokazuju da u očvršćivanju sudjeluju anorganski hidracijski produkt, polimerna mreža i jutena vlakna.

\section{Ključne riječi}

Sediment rijeke Huang He, stabilizirane zemljane opeke, učvršćujuća mreža, sinergija

${ }^{a}$ College of Architecture Engineering, Zhongyuan Stručni rad University of Technology, Zhengzhou 450 007, Kina

b Department of Materials Engineering, Tianjin Chengjian University, Tianjin 300 384, Kina 